\section{Ny norsk håndbok i vaktkirurgi}

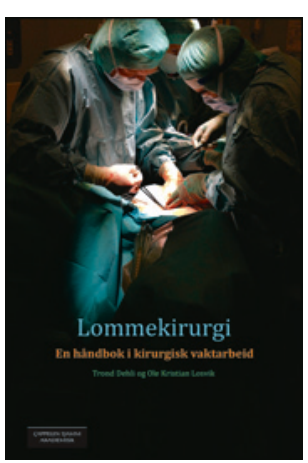

Trond Dehli, Ole Kristian Losvik Lommekirurgi

En håndbok i kirurgisk vaktarbeid. $181 \mathrm{~s}$, tab, ill. Oslo: Cappelen Damm Akademisk, 2014. Pris NOK 298

ISBN 978-82-02-44191-3

Et ferskt tilskudd til mangfoldet av kirurgiske håndbøker er den norske Lommekirurgi. Forfatterne befinner seg i hver sin ende av spesialiseringsløpet i kirurgi og har til sammen over 15 års erfaring som primærvakt. Som tittelen insinuerer, er intensjonen at boken skal kunne bæres i frakkelommen og være en lett tilgjengelig veileder ved de vanligste utfordringene man kan møte i kirurgisk vaktarbeid. Den er innbundet i myke permer med god papirkvalitet. Formatet er noe større enn andre håndbøker, men den passer godt i frakkelommen.

Boken er systematisk oppbygd med åtte kapitler og tilhørende underkapitler som til en viss grad rettferdiggjør fraværet av stikkordregister. Innledningsvis gis en kort innføring $\mathrm{i}$ «hvordan bli kirurg» og «hvordan ha vakt», og det er lett å kjenne seg igjen i problemstillingene som beskrives her. Videre omtales de vaktbærende grenspesialiteter, skader og infeksjoner i respektive kapitler. Ett kapittel tar for seg vanlige problemstillinger hos «den kirurgiske pasient», som postoperative komplikasjoner og blodfortynnende medisiner. Det siste kapitlet i boken inneholder aktuelle tabeller og skåringssystemer, mal for kirurgisk innkomstjournal og operasjonsliste i generell kirurgi.

Boken er strukturert og velskrevet med et lettfattelig språk. Den gir en kortfattet og god oversikt over utredning og behandling av vanlige akuttkirurgiske tilstander og inneholder også praktiske tips vedrørende diagnostikk og prosedyrer. Den er mindre stikkordpreget enn andre håndbøker, noe som gjør den lettlest. Teksten er beriket med egenopplevde kasuistikker, relevante tabeller, definisjoner og historiske «fun facts» som gjør den både morsom og interessant å lese. Til flere av temaene er det også oppgitt referanser for videre lesning. Boken inneholder fine bilder, illustrasjoner og røntgenbilder, men det kunne med fordel ha vært mer av dette. Jeg savner også omtale av relevante medisinske problemstillinger man kan møte på vakt, som inflammatorisk tarmsykdom, diabetes mellitus osv.

Lommekirurgi er en god norsk håndbok, og jeg mener den egner seg godt for studenter og nyutdannede leger i kirurgisk vaktarbeid. Jeg vil tro at alle i målgruppen for denne boken også har en smarttelefon i lommen. Kan man håpe at den også kommer som applikasjon til iOS/android?

\section{Henrik Røkkum}

Lege i spesialisering, Kirurgisk avdeling

Bærum sykehus

Vestre Viken HF

\section{Velskrevet og lettlest om ledelse som virker}

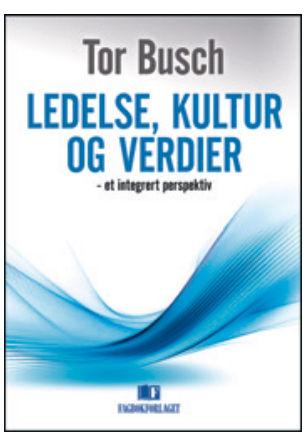

Tor Busch

Ledelse, kultur og verdier

Et integrert perspektiv. 159 s, tab, ill. Bergen:

Fagbokforlaget, 2014. Pris NOK 359

ISBN 978-82-450-1622-2

Som undertittelen antyder, tar forfatteren mål av seg til å presentere et integrert perspektiv på ledelse. Bokens formål er å vise at verdier er en sentral dimensjon i alle typer organisasjoner, og i all ledelse. Den henvender seg derfor til alle som er interessert i ledelse og verdienes funksjon i moderne, komplekse organisasjoner.

Det første av de totalt sju kapitlene er en introduksjon til ulike begreper og modeller for å studere og forstå kulturens betydning for organisasjon og ledelse. Busch beskriver en konkret modell som kan benyttes for å få klarhet i hvordan en organisasjon fungerer, og hvor det er nødvendig å ha særskilt oppmerksomhet. Dette kapitlet er utgangspunktet for de neste seks kapitlene. Hvert kapittel avsluttes med praktiske øvingsoppgaver. På den måten fremstår boken også som en lærebok som kan benyttes til individuell læring, men også i grupper og i forbindelse med lederutviklingsprogrammer.

Forfatteren uttrykker seg presist og poengtert, og det gjør boken lett å lese også for den som ikke har lest ledelsesteori tidligere. Gjennom en grundig innføring i hva verdier er, og hvordan de påvirker individer, organisasjoner og samfunn, legger kapittel 2 grunnlaget for resten av boken. Her gjennomgås også sentrale begreper knyttet til etikk på en oversiktlig og god måte.

Derfra beveger forfatteren seg inn i det som kalles verdibasert ledelse. Han gjennomgår alle de sentrale ledelsesteoriene, og hvordan de kan anses å forenes i nettopp verdibasert ledelse. Han er opptatt av verdidimensjonen som grunnlag for organisasjonskulturen, og at ledelsesdimensjonen må ses i sammenheng med det. Han sier at «ledelse uten verdier er utenkelig».

Han omtaler også ledelse som en språkskapende prosess, et interessant og kanskje undervurdert perspektiv for helsevesenets side. Hvis ikke språket som brukes, gjenspeiler de kulturelle verdiene $i$ en organisasjon, er det vanskelig å utøve effektiv ledelse. Her er det nærliggende å trekke en parallell til diskusjonen rundt begrepene som forbindes med New Public Management, og de opplevde verdiene hos de som arbeider i helsesektoren.

Jeg synes det var svært nyttig å lese denne boken, og jeg kan anbefale den til alle som interesserer seg for organisasjonskultur, og for hva som er forutsetninger for å utøve ledelse. Ledelse kan ifølge forfatteren betraktes som et målformulerende, problemløsende og språkskapende samspill. Med andre ord er det avgjørende for ledere, ikke minst i helsevesenet, å forstå profesjonskulturenes identitet og verdier, og dermed kunne uttrykke seg på en måte som skaper motivasjon for å medvirke til å nå organisasjonens mål.

Lisbeth Sommervoll

Klinikksjef, Medisinsk klinikk

Sykehuset i Vestfold 